This item was submitted to Loughborough's Research Repository by the author.

Items in Figshare are protected by copyright, with all rights reserved, unless otherwise indicated.

\title{
Heat wave adaptations for UK dwellings and development of a retrofit toolkit
}

PLEASE CITE THE PUBLISHED VERSION

http://dx.doi.org/10.1108/IJDRBE-08-2012-0026

\section{PUBLISHER}

(c) Emerald Group Publishing Limited

\section{VERSION}

AM (Accepted Manuscript)

\section{LICENCE}

CC BY-NC-ND 4.0

\section{REPOSITORY RECORD}

Porritt, Stephen, Paul C. Cropper, Li Shao, and Chris I. Goodier. 2019. "Heat Wave Adaptations for UK Dwellings and Development of a Retrofit Toolkit”. figshare. https://hdl.handle.net/2134/14028. 
This item was submitted to Loughborough's Institutional Repository (https://dspace.lboro.ac.uk/) by the author and is made available under the following Creative Commons Licence conditions.

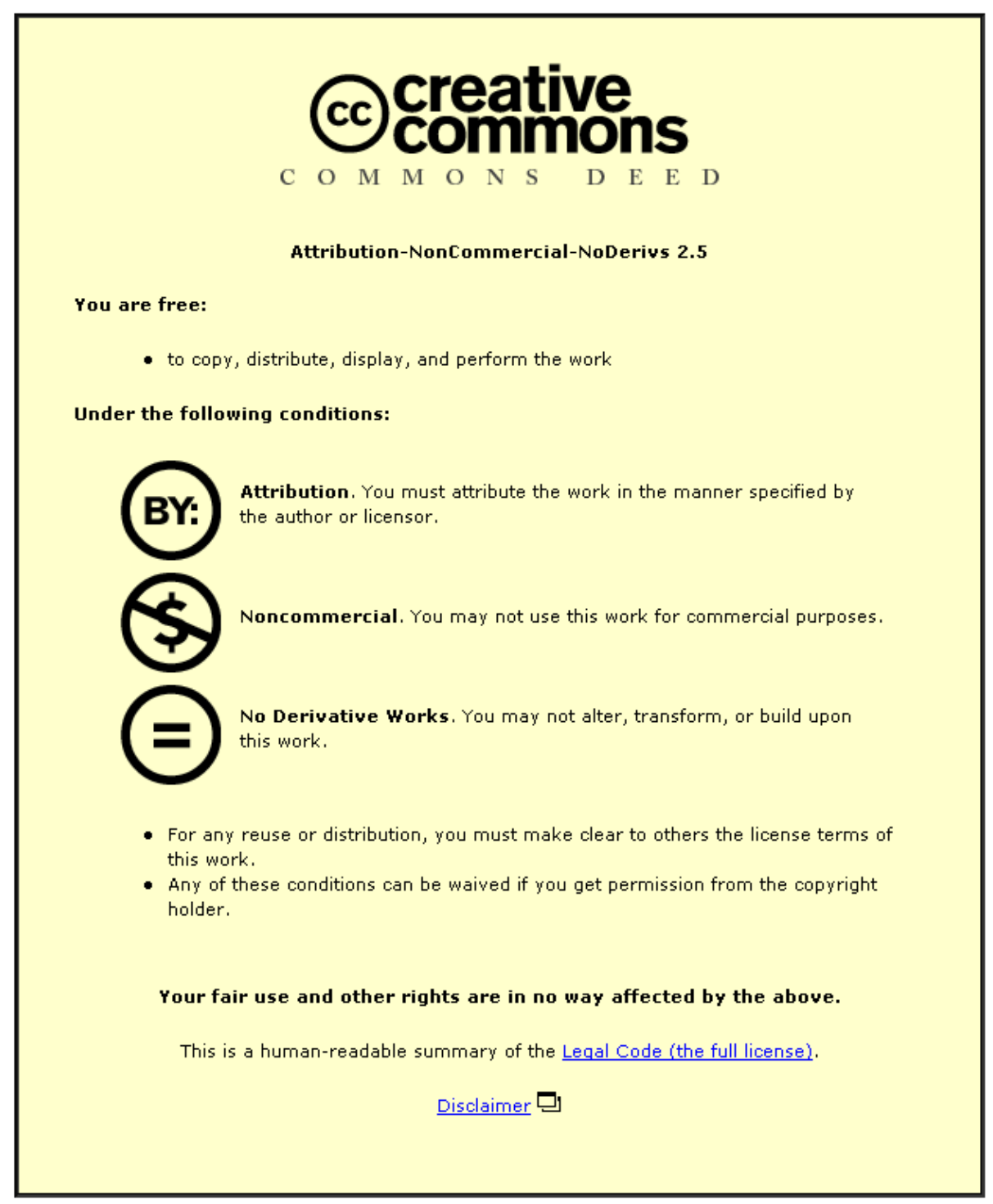

For the full text of this licence, please go to: http://creativecommons.org/licenses/by-nc-nd/2.5/ 
International Journal of

Emerald Disaster Resilience

in the Built Environment

\section{Heat wave adaptations for UK dwellings and introducing a retrofit toolkit}

\begin{tabular}{|r|l|}
\hline Journal: & International Journal of Disaster Resilience in the Built Environment \\
\hline Manuscript ID: & IJDRBE-Aug-2012-0026.R4 \\
\hline Manuscript Type: & Research Paper \\
\hline Keywords: & $\begin{array}{l}\text { Built environment, Retrofitting, Climate change, Vulnerable groups, } \\
\text { Extreme weather events, Risk reduction }\end{array}$ \\
\hline
\end{tabular}

SCHOLARONE ${ }^{m}$

Manuscripts 


\section{Article Title Page}

\section{Author Details}

Stephen M Porritt, Institute of Energy and Sustainable Development, De Montfort University, UK

Paul C Cropper, of Energy and Sustainable Development, De Montfort University, Leicester, UK

Li Shao, School of Construction Management and Engineering, University of Reading, Reading, UK

Chris I Goodier, School of Civil and Building Engineering, Loughborough University, Loughborough, UK
\end{abstract}

Heat wave adaptations for UK dwellings and development of a retrofit toolkit
Corresponding Author: Stephen M Porritt

Corresponding Author's Email: sporritt@dmu.ac.uk

\section{Acknowledgments:}

This research was funded by the Engineering and Physical Sciences Research Council (EPSRC) as part of the "Community Resilience to Extreme Weather" (CREW) project (grant number EP/F036442/1). Their financial support is gratefully acknowledged. Further details are available at www.extreme-weather-impacts.net

\section{Biographical Details:}

Dr Stephen Porritt is a Research Fellow at the Institute of Energy and Sustainable Development (IESD) at De Montfort University, Leicester, UK. His research interests include dynamic thermal modelling of buildings, climate change adaptation, retrofit of dwellings and monitoring of buildings to validate simulation results.

Dr Paul Cropper is a Senior Research Fellow in the IESD, with research interests in computer simulation applied to building design and the indoor environment. He has recently been involved in a project developing techniques to couple Computational Fluid Dynamics with a model of human physiology and human comfort.

Li Shao is Professor in Sustainable Technology for the Built Environment at the School of Construction Management and Engineering, University of Reading.

Dr Chris Goodier is a Senior Lecturer and an experienced Civil Engineer and Researcher with 20 years experience of all aspects of construction, including contracting, consultancy and research. His research encompasses civil engineering materials and offsite technologies, community energy, urban energy systems, and construction futures and scenarios.

\section{Structured Abstract:}

Purpose - Dwelling retrofit strategies generally concentrate on measures to reduce energy use and carbon emissions. However, climate change projections predict increases in both the frequency and severity of extreme weather events, including heat waves. It is predicted that by the 2040s severe heat waves similar to the European one in August 2003 may be expected to occur every year. Future guidance therefore needs to combine mitigation with adaptation in order to provide safe and comfortable dwellings, whilst also reducing heating energy use, within the available retrofit budget.

Design/methodology/approach - The research presented here used dynamic thermal simulation (EnergyPlus) to model a range of passive interventions on selected dwelling types to predict the effect on both dwelling overheating during a heat wave and annual space heating energy use. The interventions include modifications and additions to solar control, insulation and ventilation.

Findings - Results demonstrate the effectiveness of interventions that reduce solar heat gains, with external shutters fitted to windows being the most effective single intervention in many cases. Solar reflective coatings also reduce overheating but lead to increased winter heating energy use, whilst wall insulation reduces heating energy use but can, in some cases, lead to increased overheating. The choice of wall insulation type is shown to be very important, with external insulation consistently performing better than internal for overheating reduction. The modelling further demonstrates that combined interventions can significantly reduce or in many cases eliminate overheating. Overheating exposure was found to vary significantly (up to a factor of 10 times) between dwelling types. It can be significantly greater for residents who have to stay at home during the daytime, such as the elderly or infirm, and different interventions are sometimes more suitable in these cases.

Originality/value - An innovative modelling methodology integrating overheating reduction, heating energy use and intervention cost has been developed and implemented for adapting UK dwellings to future heat waves. Other innovations include an automated approach for large volumes of simulations (over 180,000); a unique graphical interpretation method for presenting single and combined intervention results; and a user-friendly, interactive retrofit toolkit, which is available online for public access and free of charge.

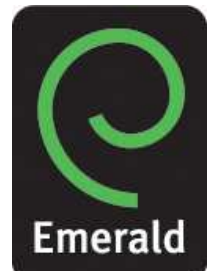




\section{Type header information here}

2

3

4

5

6

7

8

9

10

11

12

13

14

15

16

17

18

19

20

21

22

23

24

25

26

27

28

29

30

31

32

33

34

35

36

37

38

39

40

41

42

43

44

45

46

47

48

49

50

51

52

53

54

55

56

57

58

59

60

Keywords: Heat wave; housing; overheating; adaptation; retrofit; intervention; building simulation; cost; toolkit Article Classification: Research Paper

For internal production use only

Running Heads: 


\title{
Heat wave adaptations for UK dwellings and introducing a retrofit toolkit
}

\author{
1 Introduction \\ Historically overheating has not been regarded as a major problem in UK dwellings and \\ the main focus for refurbishment has centred on measures to reduce heating energy use \\ and mitigate carbon emissions. However, energy efficiency improvements that increase \\ insulation and airtightness could lead to increased summertime overheating, with \\ consequential risks to health (Davies and Oreszczyn, 2012). A warming climate, with \\ predicted increases in both the frequency and severity of extreme weather events \\ (including heat waves), has therefore refocused the retrofit agenda to combine \\ mitigation with adaptation. \\ This paper presents research into passive technological and people-based coping \\ measures undertaken during the Community Resilience to Extreme Weather project \\ (CREW, 2012) and introduces a web-based retrofit toolkit that enables easy comparison \\ of the effect of a range of interventions. The aim of the project was to provide holistic \\ retrofit guidance for designers, homeowners and decision makers.
}

\section{Background}

The heat wave in August 2003 resulted in around 45,000 excess deaths across 12 European countries, almost 2,000 of which were in England and Wales (Robine et al., 2008). The latest climate change projections (Murphy et al., 2009) indicate that such events will occur as often as each year by the middle of this century.

Most of the victims in the 2003 heat wave were elderly or vulnerable and living in the major cities. Top floor flats, particularly those where attic bedrooms had poorly insulated roofs, were associated with increased mortality in Paris (Vandentorren et al., 2006). Monitoring during the 2003 heat wave in London also highlighted severe overheating in flats, with one recording internal temperatures of up to $39.2^{\circ} \mathrm{C}$ (Wright et al., 2005). Modern methods of construction can also result in higher levels of overheating as better insulation and increased airtightness more effectively trap heat gains inside dwellings. Concerns about overheating in modern houses led to the publication of design guidance (Orme and Palmer, 2003), which identified control of solar and casual gains as well as coupling thermal mass with night ventilation as key design approaches.

The Department for Communities and Local Government (DCLG) in the UK recently published an investigation into overheating in homes, identifying gaps in knowledge and proposed actions (DCLG, 2012). The report identifies the lack of guidance for a range of audiences and also suggests a review of retrofit measures aimed at reducing energy use that may lead to a risk of increased overheating. Development of a design tool is also suggested in the report. 
The Chartered Institution of Building Services Engineers (CIBSE) produced guidance in Technical Report TM36 addressing overheating in several case study buildings, including dwellings (CIBSE, 2005). This was important pioneering work, although with some limitations. For example, with the exception of some solar shading analysis, TM36 does not consider the effect of individual interventions and it does not consider different occupancy profiles within the same dwelling type. Arup, the authors of CIBSE TM36, also produced a report for the Three Regions Climate Change Group (Arup, 2008), which provides retrofit guidance for policymakers, housing professionals and householders. The report compares the benefits and limitations of a range of interventions, including some approximate costs. The Greater London Authority (GLA) has also published overheating guidance in its climate change adaptation strategy (GLA, 2011), whilst the Heatwave Plan for England (Department of Health, 2013) provides guidance for coping with heat waves, with a particular focus on the elderly and vulnerable.

Several other projects have investigated adaptation and resilience to a changing climate. The SCORCHIO project (Lee and Sharples, 2008; Smith et al., 2009) investigated the urban heat island effect for the UK cities of Manchester and Sheffield, using dynamic thermal modelling to assess the effect of orientation, glazing, insulation and internal and external shading. The LUCID project (Mavrogianni et al., 2009, 2011, 2012) modelled the impact of climate change and the urban heat island effect in London, where insulation and glazing upgrades were assessed using dynamic thermal modelling for a range of dwelling variants. The SNACC project was primarily focussed on neighbourhood level adaptation, using future probabilistic weather scenarios to assess a range of retrofit packages (Gupta and Gregg, 2012).

This research aims to address some of the identified gaps, expanding on previous research and specifically providing detailed quantitative information on the overheating risk associated with different dwelling types and how that changes according to occupancy (for example elderly or vulnerable residents) and dwelling orientation. This research also highlights issues surrounding the installation of mitigation measures, for example internal wall insulation, which in some cases can lead to increased overheating. A retrofit toolkit is introduced that allows comparison of adaptation measures, considering not only overheating performance but also annual heating energy use and intervention cost.

\section{Research Methodology}

The project study area comprised five of the South London Boroughs, whilst South East England is identified in the UK Climate Projections as being the region most at risk from future overheating (Murphy et al., 2009). The dwellings for modelling were therefore chosen to be representative of the built form and construction methods found in London and South East England. The 2009 English House Condition Survey (EHCS) (DCLG, 2009) was used to analyse the housing stock and select the dwellings for modelling (Figure 1). 


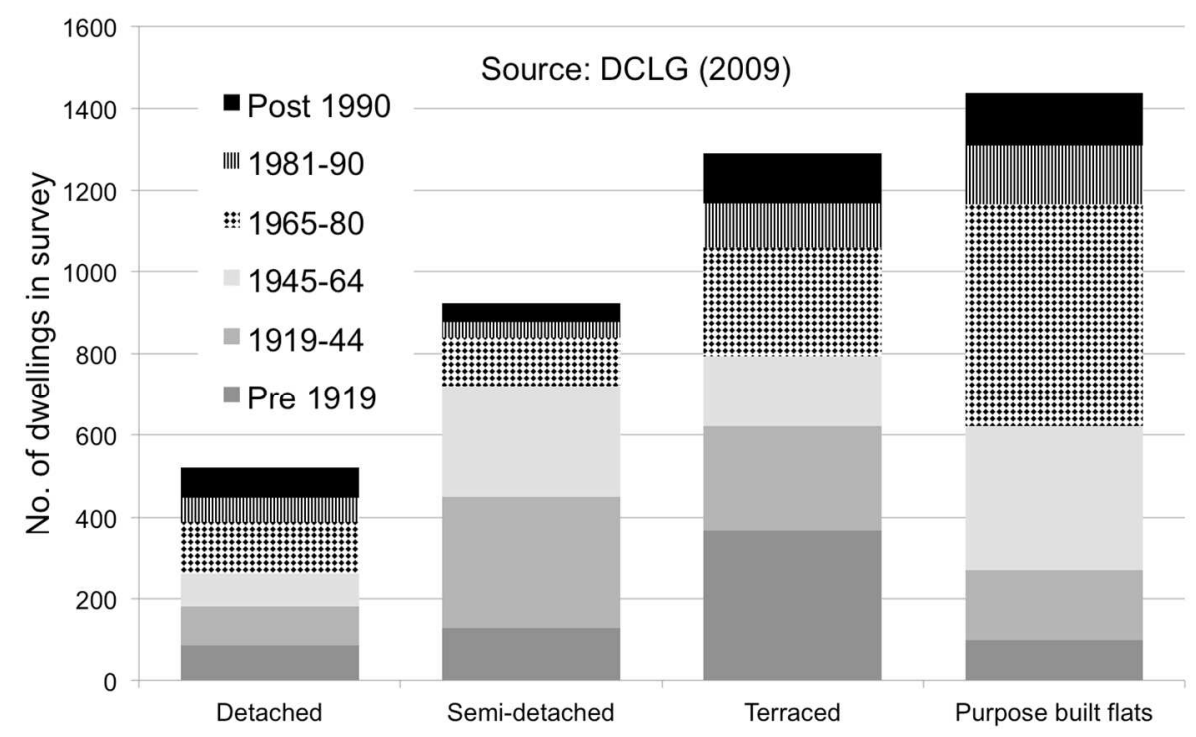

Figure 1. Housing stock by type and age, London and S.E. England

The time taken to complete the simulation process and data analysis limited the number of dwellings that could be modelled to four archetypes (Figure 2), providing seven dwelling variants: $19^{\text {th }}$ century end and mid-terraced houses; a 1930s semi-detached house; 1960s ground, mid and top floor flats; and a modern detached house. The EHCS data includes statistics on glazing type and insulation across the housing stock and this data was used to specify the base case dwellings (Table 1). Further details on the dwelling models, including floor plans, can be found in (Porritt, 2012a).

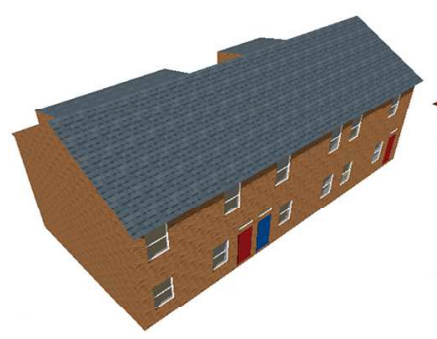

19th Century Terraced

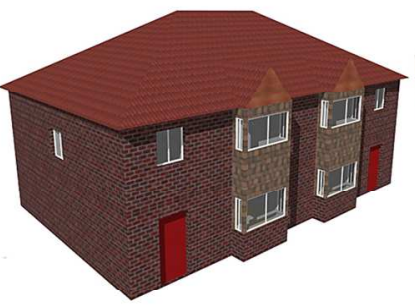

1930s Semi-detached

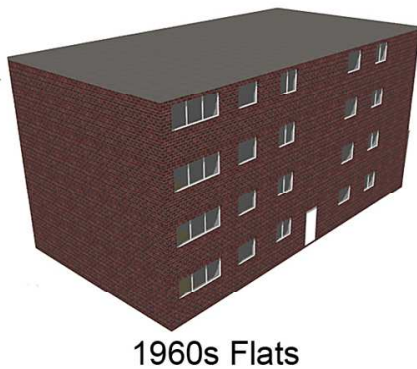

1960s Flats

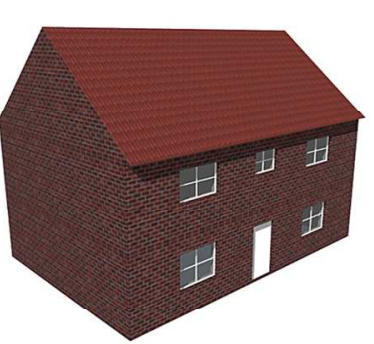

Modern Detached

Figure 2. Dwellings selected for modelling

Dynamic thermal simulation was used to model the effects of the selected interventions on dwelling overheating and space heating energy use. The simulation models were constructed using DesignBuilder (2012), which uses the EnergyPlus simulation engine (U.S. Department of Energy, 2010). EnergyPlus was chosen because it has undergone a range of validation tests (U.S. Department of Energy, 2012), is widely used in academia and industry, and could be controlled by a parametric simulation interface 
(Zhang, 2009). Full details of the modelling methods, including internal gains and ventilation assumptions, have been presented in previous publications (Porritt et al., 2012; Porritt, 2012a).

\begin{tabular}{|c|c|c|c|c|}
\hline & $\begin{array}{l}\text { 19thC } \\
\text { Terraced }\end{array}$ & $\begin{array}{l}\text { 1930s } \\
\text { Semi-detached }\end{array}$ & $\begin{array}{l}\text { 1960s } \\
\text { Flats }\end{array}$ & $\begin{array}{l}\text { Modern } \\
\text { Detached }\end{array}$ \\
\hline External walls & Solid brick & $\begin{array}{l}\text { Brick cavity } \\
\text { uninsulated }\end{array}$ & $\begin{array}{l}\text { Brick/block cavity } \\
\text { uninsulated, }\end{array}$ & $\begin{array}{l}\text { Brick/block cavity } \\
\text { insulated }\end{array}$ \\
\hline $\begin{array}{l}\text { Wall U-Value } \\
\left(\mathrm{W} / \mathrm{m}^{2} \mathrm{~K}\right)\end{array}$ & 2.12 & 1.43 & 1.37 & 0.27 \\
\hline $\begin{array}{l}\text { Wall solar } \\
\text { absorptivity }\end{array}$ & 0.6 & 0.7 & 0.7 & 0.7 \\
\hline Roof & $\begin{array}{l}\text { Clay tiles } \\
0.1 \mathrm{~m} \text { insulation }\end{array}$ & $\begin{array}{l}\text { Concrete tiles } \\
0.1 \mathrm{~m} \text { insulation }\end{array}$ & $\begin{array}{l}\text { Cold roof type } \\
0.05 \mathrm{~m} \text { insulation }\end{array}$ & $\begin{array}{l}\text { Concrete tiles } \\
0.3 \mathrm{~m} \text { insulation }\end{array}$ \\
\hline $\begin{array}{l}\text { Roof U-Value } \\
\left(\mathrm{W} / \mathrm{m}^{2} \mathrm{~K}\right)\end{array}$ & 0.36 & 0.37 & 0.59 & 0.13 \\
\hline $\begin{array}{l}\text { Roof solar } \\
\text { absorptivity }\end{array}$ & 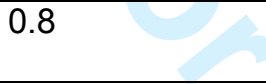 & 0.7 & 0.85 & 0.7 \\
\hline Internal partitions & $\begin{array}{l}\text { Solid brick with } \\
\text { plaster }\end{array}$ & $\begin{array}{l}\text { Solid brick with } \\
\text { plaster }\end{array}$ & $\begin{array}{l}\text { Plasterboard with } \\
\text { air gap }\end{array}$ & $\begin{array}{l}\text { Block with } \\
\text { plasterboard }\end{array}$ \\
\hline Ground floor & $\begin{array}{l}\text { Suspended } \\
\text { timber, } \\
\text { uninsulated }\end{array}$ & $\begin{array}{l}\text { Concrete } \\
\text { uninsulated }\end{array}$ & $\begin{array}{l}\text { Concrete } \\
\text { uninsulated }\end{array}$ & $\begin{array}{l}\text { Concrete block } \\
\text { and beam, } \\
\text { insulated }\end{array}$ \\
\hline $\begin{array}{l}\text { Ground floor } \\
\text { U-Value }\left(\mathrm{W} / \mathrm{m}^{2} \mathrm{~K}\right)\end{array}$ & 0.84 & 1.10 & 0.90 & 0.21 \\
\hline Windows & $\begin{array}{l}\text { Double glazing, } \\
\text { uPVC frame }\end{array}$ & $\begin{array}{l}\text { Double glazing, } \\
\text { uPVC frame }\end{array}$ & $\begin{array}{l}\text { Double glazing, } \\
\text { uPVC frame }\end{array}$ & $\begin{array}{l}\text { Double glazing, } \\
\text { uPVC frame }\end{array}$ \\
\hline $\begin{array}{l}\text { Window U-Value } \\
\left(\mathrm{W} / \mathrm{m}^{2} \mathrm{~K}\right)\end{array}$ & 2.70 & 2.70 & 2.70 & 1.96 \\
\hline Glazing SHGC $^{1}$ & 0.71 & 0.71 & 0.71 & 0.69 \\
\hline $\begin{array}{l}\text { Infiltration (air } \\
\text { changes /hour) }\end{array}$ & 0.7 & 0.55 & 0.5 & 0.5 \\
\hline
\end{tabular}

Table 1. Base case models construction and thermal properties

The interventions applied in this research (Table 2) could be split into three categories: insulation, solar control and ventilation. Some were purely physical changes or additions, such as increased insulation and solar reflective coatings. Others were behavioural changes, for example preventing window opening when the outside air temperature was higher than inside (Window Rules). Some interventions combined physical additions with behavioural changes to achieve correct operation, such as fitting external shutters to the windows. Some of the interventions could not be applied to all dwelling types, for example cavity wall insulation was not an option for the older solid wall terraced houses. Insulation upgrades may also be difficult to justify for modern, well-insulated dwellings and were therefore not considered. Other obstacles may exist, including planning constraints, governing changes to external appearance that could limit the range of potential interventions. Cost may also limit the uptake of some interventions and this is addressed later.

\footnotetext{
${ }^{1} \mathrm{SHGC}=$ Solar heat gain coefficient
} 
Insulation interventions were selected to comply with UK Building Regulations in force at the time the simulations were carried out (Office of the Deputy Prime Minister, 2006). It was assumed that draught proofing would be improved during the installation of wall insulation, resulting in lower background infiltration. Window shading devices (blinds, shutters and curtains) were selected from the EnergyPlus materials database.

\begin{tabular}{|c|c|c|c|}
\hline Category & Intervention & Dwellings* $^{*}$ & Description \\
\hline \multirow[t]{5}{*}{ Insulation } & $\begin{array}{l}\text { Loft insulation } \\
\text { (terraced/semi) }\end{array}$ & $\mathrm{T}, \mathrm{S}$ & Increase loft insulation to $0.25 \mathrm{~m}\left(\mathrm{U}-\mathrm{value}\right.$ of $\left.0.16 \mathrm{~W} / \mathrm{m}^{2} \mathrm{~K}\right)$ \\
\hline & $\begin{array}{l}\text { Upgrade roof } \\
\text { (flats) }\end{array}$ & $\mathrm{F}$ & $\begin{array}{l}\text { Felt, plywood deck, } 0.14 \mathrm{~m} \text { EPS insulation, } 0.0095 \mathrm{~m} \\
\text { plasterboard (U-value } 0.25 \mathrm{~W} / \mathrm{m}^{2} \mathrm{~K} \text { ) }\end{array}$ \\
\hline & $\begin{array}{l}\text { External wall } \\
\text { insulation }\end{array}$ & $\mathrm{T}, \mathrm{S}, \mathrm{F}$ & $\begin{array}{l}\text { Addition of } 0.06 \mathrm{~m} \text { phenolic foam and } 0.02 \mathrm{~m} \text { render to } \\
\left.\text { outside face of external walls (U-value } 0.35 \mathrm{~W} / \mathrm{m}^{2} \mathrm{~K}\right) \text {. } \\
\text { Background infiltration reduced to } 0.5 \mathrm{ACH} \text { for terraced } \\
\text { and semi }\end{array}$ \\
\hline & $\begin{array}{l}\text { Internal wall } \\
\text { insulation }\end{array}$ & $\mathrm{T}, \mathrm{S}, \mathrm{F}$ & $\begin{array}{l}\text { Addition of } 0.06 \mathrm{~m} \text { phenolic foam and } 0.013 \mathrm{~m} \text { plasterboard } \\
\text { to inside face of external walls }\left(\mathrm{U} \text {-value } 0.35 \mathrm{~W} / \mathrm{m}^{2} \mathrm{~K}\right) \\
\text { Background infiltration reduced to } 0.5 \mathrm{ACH} \text { for terraced } \\
\text { and semi }\end{array}$ \\
\hline & $\begin{array}{l}\text { Cavity wall } \\
\text { insulation }\end{array}$ & $\mathrm{S}, \mathrm{F}$ & $\begin{array}{l}\text { Addition of } 0.05 \mathrm{~m} \text { mineral wool insulation to cavity (U- } \\
\left.\text { value } 0.5 \mathrm{~W} / \mathrm{m}^{2} \mathrm{~K}\right)\end{array}$ \\
\hline \multirow[t]{7}{*}{$\begin{array}{l}\text { Solar } \\
\text { Control }\end{array}$} & Internal blinds & $\mathrm{T}, \mathrm{S}, \mathrm{F}, \mathrm{D}$ & $\begin{array}{l}\text { High reflectivity slats, solar transmittance } 0 \text {, solar } \\
\text { reflectance } 0.8 \text {, material conductivity } 0.9 \mathrm{~W} / \mathrm{m}-\mathrm{K} \text {, closed } \\
\text { from } 0900 \text { to } 1800\end{array}$ \\
\hline & $\begin{array}{l}\text { External } \\
\text { shutters }\end{array}$ & $\mathrm{T}, \mathrm{S}, \mathrm{F}, \mathrm{D}$ & $\begin{array}{l}\text { High reflectivity slats, solar transmittance } 0 \text {, solar } \\
\text { reflectance } 0.8, \text { material conductivity } 0.9 \mathrm{~W} / \mathrm{m}-\mathrm{K} \text {, closed } \\
\text { from } 0900 \text { to } 1800\end{array}$ \\
\hline & $\begin{array}{l}\text { Internal } \\
\text { curtains }\end{array}$ & $\mathrm{T}, \mathrm{S}, \mathrm{F}, \mathrm{D}$ & $\begin{array}{l}\text { Close weave medium drapes, solar transmittance } 0.05 \text {, } \\
\text { solar reflectance } 0.3 \text {, material conductivity } 0.1 \mathrm{~W} / \mathrm{m}-\mathrm{K} \text {, } \\
\text { closed from } 0900 \text { to } 1800\end{array}$ \\
\hline & Fixed shading & $\mathrm{T}, \mathrm{S}, \mathrm{F}, \mathrm{D}$ & $\begin{array}{l}\text { Add 1.0m deep overhangs above south, east and west } \\
\text { windows ( } 2.0 \mathrm{~m} \text { deep awnings for east and west ground } \\
\text { floor windows, except terraced houses for front elevations) }\end{array}$ \\
\hline & Light walls & $\mathrm{T}, \mathrm{S}, \mathrm{F}, \mathrm{D}$ & $\begin{array}{l}\text { Coat external walls with high performance solar reflective } \\
\text { paint to reduce solar absorptivity to } 0.15\end{array}$ \\
\hline & Light roof & $\mathrm{T}, \mathrm{S}, \mathrm{F}, \mathrm{D}$ & $\begin{array}{l}\text { Coat roof tiles with high performance solar reflective paint } \\
\text { to reduce solar absorptivity to } 0.15\end{array}$ \\
\hline & $\begin{array}{l}\text { Low e triple- } \\
\text { glazing }\end{array}$ & $\mathrm{T}, \mathrm{S}, \mathrm{F}, \mathrm{D}$ & $\begin{array}{l}\text { Replace double-glazing with low emissivity coated triple- } \\
\text { glazing: } 3 \times 0.003 \mathrm{~m} \text { panes with } 0.012 \mathrm{~m} \text { air gaps, inner and } \\
\text { outer panes coated, SHGC } 0.472 \text {, light transmission } 0.661 \text {, } \\
\text { U-value } 1.6 \mathrm{~W} / \mathrm{m}^{2} \mathrm{~K}\end{array}$ \\
\hline \multirow[t]{2}{*}{ Ventilation } & $\begin{array}{l}\text { Night } \\
\text { ventilation }\end{array}$ & $\mathrm{T}, \mathrm{S}, \mathrm{F}, \mathrm{D}$ & $\begin{array}{l}\text { Ventilation of unoccupied rooms with cooler outside night } \\
\text { air at } 8 \text { air changes per hour (may require low power fans if } \\
\text { security or noise is an issue, preventing window opening) }\end{array}$ \\
\hline & Window rules & $\mathrm{T}, \mathrm{S}, \mathrm{F}, \mathrm{D}$ & $\begin{array}{l}\text { Prevent windows from being opened (reduce ventilation to } \\
\text { background infiltration only) if outside air temperature is } \\
\text { greater than inside air temperature }\end{array}$ \\
\hline
\end{tabular}

Table 2 Modelled interventions 
This project was primarily concerned with adaptations to cope with extreme weather events, including heat waves. The current CIBSE Design Summer Year (DSY) weather files provide hot, but not extreme, weather data for use in building design overheating assessments. Future weather files, created through a morphing procedure (Belcher et al., 2005) have been used in previous overheating studies (CIBSE, 2005; Arup, 2008). These use current CIBSE weather files, both DSY and TRY (Test Reference Year) that have been modified using the UKCIP02 climate projections (Hulme et al., 2002). However, it was found that 2080s weather files were required to provide heat wave periods approaching the severity of August 2003. The latest probabilistic weather projections (Murphy et al., 2009) were released with a Weather Generator Tool that can be used to produce simulation weather files, although spells of similar weather patterns, such as those that constitute heat wave periods, are not well represented (Jones et al., 2010). Another option was to use real weather data from Mediterranean locations that currently approximate future UK climates. This approach has been used in previous research, for example Gaterell and McEvoy (2005) used Milan and Rome to represent future London climates. However, solar data will not match UK locations and other weather variables, such as wind speed and humidity, may be different.

The approach taken in this research was to use real weather data for London from the August 2003 heat wave. This enabled assessment of dwelling performance under a known extreme weather event. The 2003 heat wave was also an event to which a wide range of stakeholders and potential users of the research could relate. The simulation weather file was constructed using data from the British Atmospheric Data Centre (UK Meteorological Office, 2012). Figure 3 shows the August 2003 heat wave temperature for the London Heathrow weather station. Daytime temperatures peaked at over $37^{\circ} \mathrm{C}$ and the night time temperature did not drop below $18^{\circ} \mathrm{C}$. Simulations were also carried out using the current CIBSE TRY weather file to assess annual heating energy use.

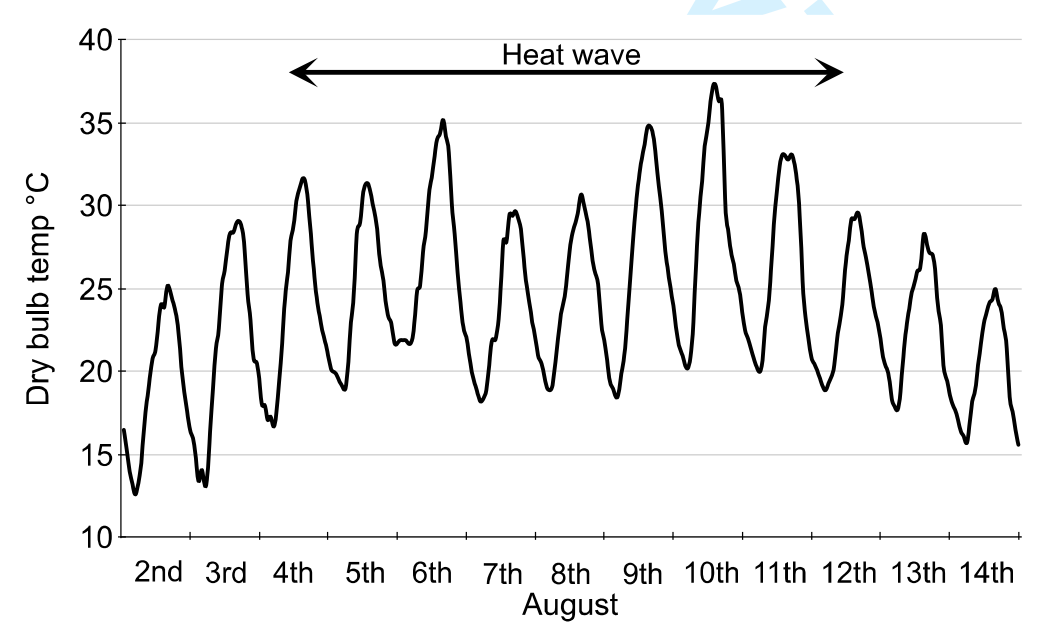

Figure 3 London Heathrow heat wave temperatures, August 2003

To assess the overheating exposure experienced by different types of occupants two occupancy profiles were used in the modelling (Table 3). The family profile assumed 
adults and school age children (number of children depending on dwelling size) who left the dwellings unoccupied during the daytime. The elderly profile assumed two elderly residents who occupied the dwellings all the time, although this could also represent other infirm or vulnerable occupants. The hours of occupation were derived from diary entries in the UK Time Use Survey 2000 (ONS, 2003).

\begin{tabular}{lcc}
\hline & Living rooms & Main bedrooms \\
\hline Family profile & $1800-2300$ & $2300-0730$ \\
Elderly profile & $0900-2230$ & $2230-0730$ \\
\hline
\end{tabular}

Table 3. Occupancy profiles

Dynamic thermal simulations were carried out for each dwelling type, assuming four different orientations and the two occupancy profiles, first using the 2003 heat wave period weather file for overheating and then using the CIBSE TRY weather file for heating energy use. Figure 4 shows an example parameter tree for one of the dwellings (semi-detached house). Modelling the possible combinations of interventions for this dwelling type resulted in 16,384 simulations for each weather file. Some of the dwellings had fewer possible interventions, for example the detached house did not have any insulation upgrades, resulting in a total of 184,320 simulations for all variants.

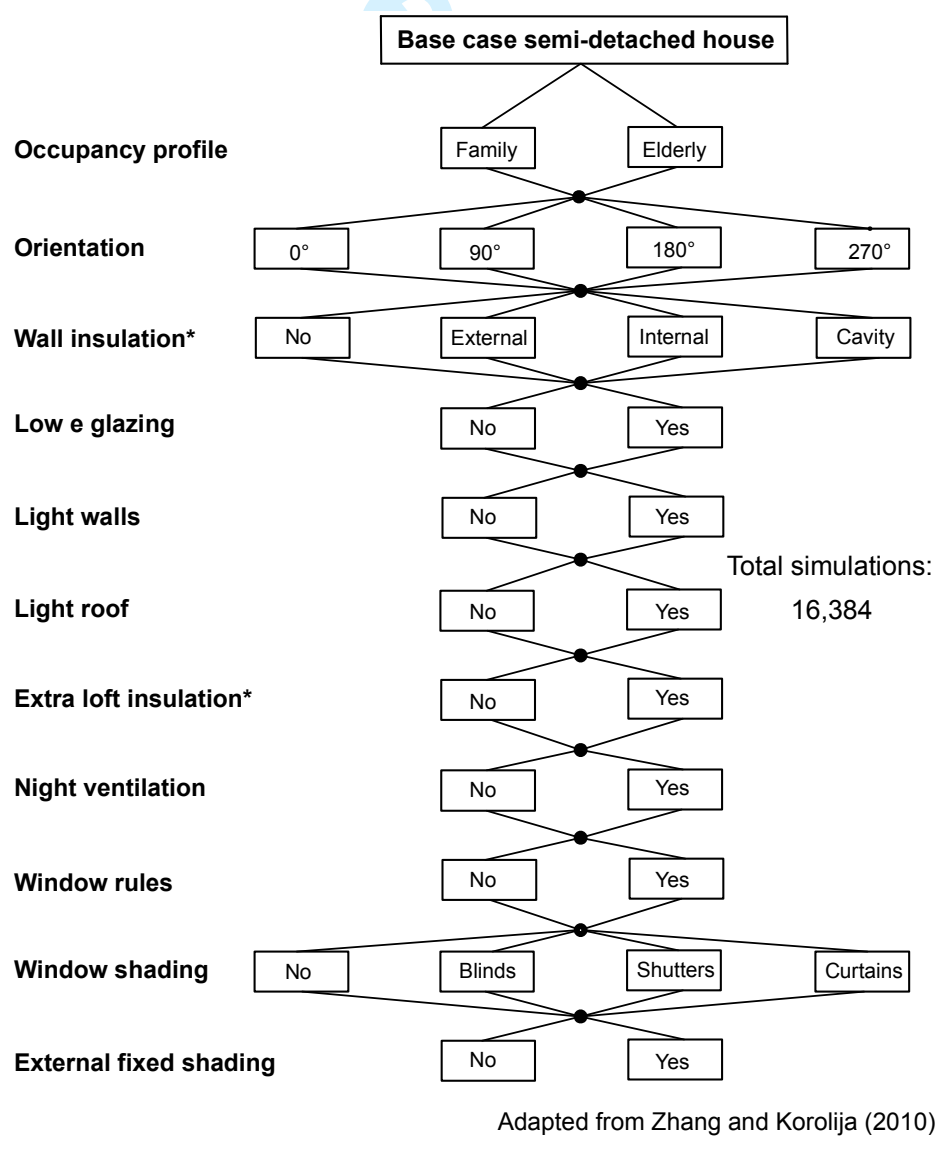

Figure 4. Combined interventions parameter tree 
The estimated cost of interventions was included in the analysis to provide holistic guidance for users of the retrofit toolkit (Section 4.3). No single source of cost information could be found that covered the full range of modelled interventions, therefore a variety of sources was used, published between 2009 and 2012. A report for the Energy Saving Trust (2009) provided detailed information on the costs of solid wall insulation, whilst the Energy Saving Trust (2012) provided typical installed costs for loft and cavity wall insulation. Langdon (2011) is an architects' and builders' cost reference book that provided indicative installed costs for external fixed shading devices, solar reflective coatings (wall and roof) and replacement flat roof constructions. Costs of low-e triple glazing, external shutters and internal blinds were estimated from commercial quotes, obtained in early 2012 . These approximate costs are for the UK and exclude sales tax (VAT). They are not intended to be used as the basis for specific costing work.

CIBSE publish guideline overheating threshold temperatures for different situations (CIBSE, 2006). For dwellings the Guide suggests that operative temperatures of $28{ }^{\circ} \mathrm{C}$ for living rooms and $26{ }^{\circ} \mathrm{C}$ for bedrooms should not be exceeded for more than $1 \%$ of occupied hours. However, when comparing the effect of interventions during a heat wave period these threshold temperatures will be exceeded for much of the time and the simple 'percentage over hours' method would not allow differentiation between the different cases. Presenting the results as the number of degree hours over the CIBSE threshold temperatures, where each degree centigrade over the threshold temperature for one hour counts as one degree hour, arguably provides a better method of quantifying the degree of overheating. This method has been used in previous research (Orme and Palmer, 2003; Energy Saving Trust, 2005) and was the method chosen for this research.

\section{Results and discussion}

It is beyond the scope of this paper to present all of the simulation results for each combination of dwelling type, orientation and occupancy profile. The retrofit toolkit (Porritt, 2012b) produced as part of this research project (Section 4.3) can be used to view the full simulation results. The following sections select some example results and discuss the key findings.

\subsection{Base case dwelling overheating}

Figure 5 shows the base case overheating degree hours during occupied periods for the living room and main bedroom for each dwelling type. Two categories of dwelling were identified in terms of overheating exposure: Tier 1 dwellings $\left(19^{\text {th }}\right.$ century end and midterraced houses; 1930s semi-detached house; 1960s ground floor flat) and Tier 2 (mid and top floor 1960s flats; modern detached house). Total overheating exposure (living room plus bedroom overheating for occupied periods) was 2 to 10 times higher in Tier 2 dwellings than Tier 1. For example, elderly occupants of the top floor flat with westfacing windows experienced approximately 8 times the total overheating exposure of the same residents in the ground floor flat with north-facing windows. Elderly occupants (representing daytime occupancy) experienced typically double the overheating exposure of the family occupants, who were out of their homes during the daytime. 
Figure 5 Base case dwellings overheating exposure during the London 2003 heat wave

\subsection{Single interventions}

Figure 6 shows an example of the effect of interventions applied individually for the endterraced house with west-facing living room and east-facing main bedroom windows. The chart shows the total overheating exposure, with the interventions ranked for the family occupancy profile. The light bars show the extra overheating exposure experienced by the elderly occupants. The solid walls were effective conductors of heat and in both cases the light walls intervention (coating the external walls with a low absorptivity paint) was the best intervention for overheating reduction, with external shutters also seen to be very effective. However, the ranking order changed between the profiles for some of the interventions, indicating that certain measures were more effective depending on the type of occupant. The most significant observation was the effect of internal wall insulation. For the family occupants this had little effect on total overheating exposure (a small reduction), but for the elderly occupants, inside the living room during the daytime, the addition of internal wall insulation resulted in greater overheating than the base case. This is thought to be due to the insulation removing the connection to the thermal mass of the solid walls and more effective retention of heat gains inside the dwelling. 
End-terraced house: front west-facing (see: www.iesd.dmu.ac.uk/crew for dwelling plans)

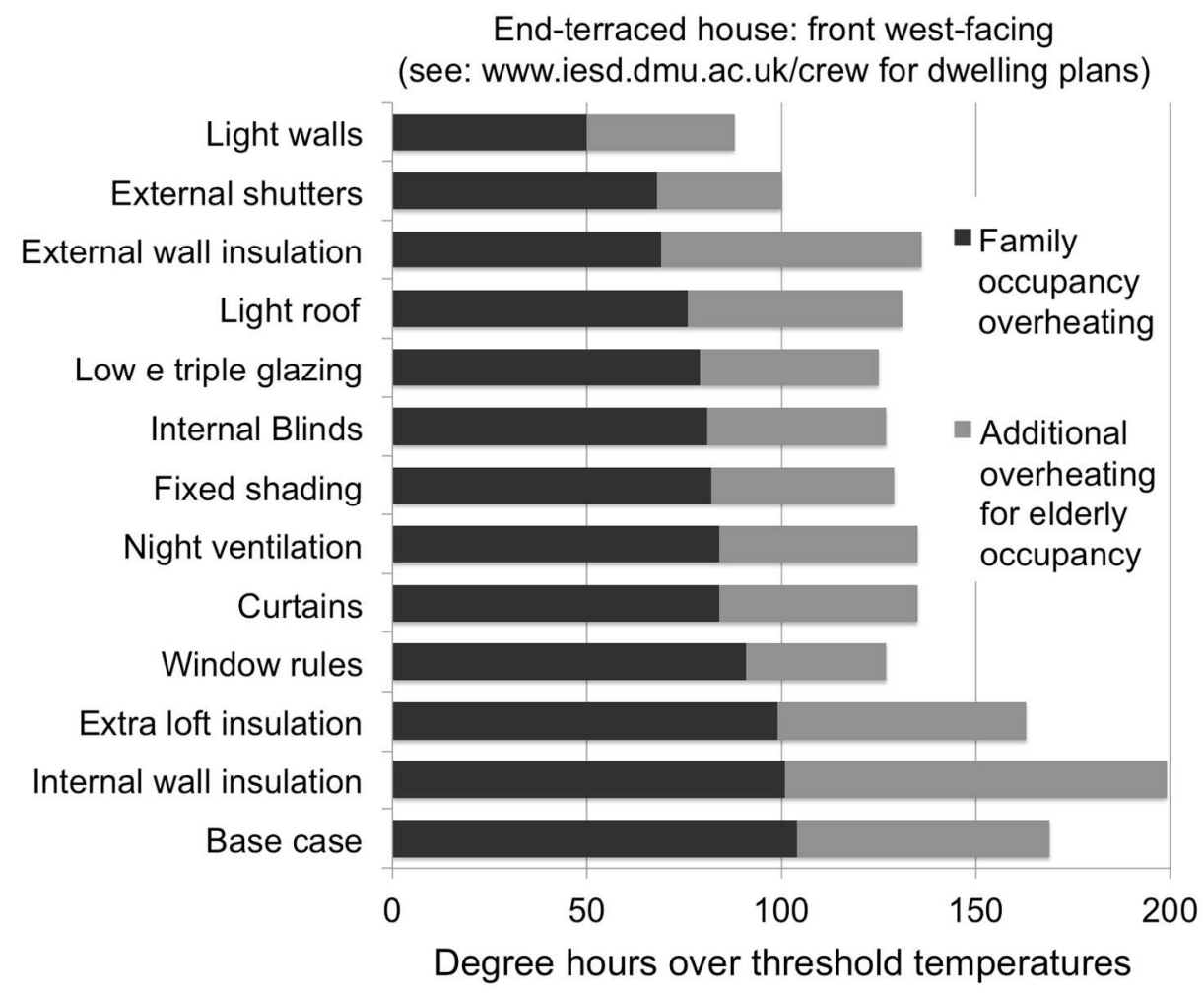

Figure 6 Single interventions effect on total overheating exposure

Behavioural interventions were generally effective in reducing overheating. The use of window rules, where occupied room windows were kept closed if the outdoor air temperature exceeded the room temperature, reduced overheating in the end-terraced case by $25 \%$ (Figure 6 ). However, it had little effect when used on its own in the higher overheating dwellings, where the room temperature often exceeded the outdoor air temperature, even during peak heat wave hours. Keeping curtains closed during the daytime was also effective, but could be impractical for daytime occupied dwellings due to the loss of view and the need to use artificial lighting. Night ventilation to unoccupied rooms removed heat gains built up during the daytime and recharged the building thermal mass, providing a radiative cooling benefit that persisted through the following day. Implementation of night ventilation requires consideration of wider practical issues, for example security of open windows at night, urban noise and pollution. 

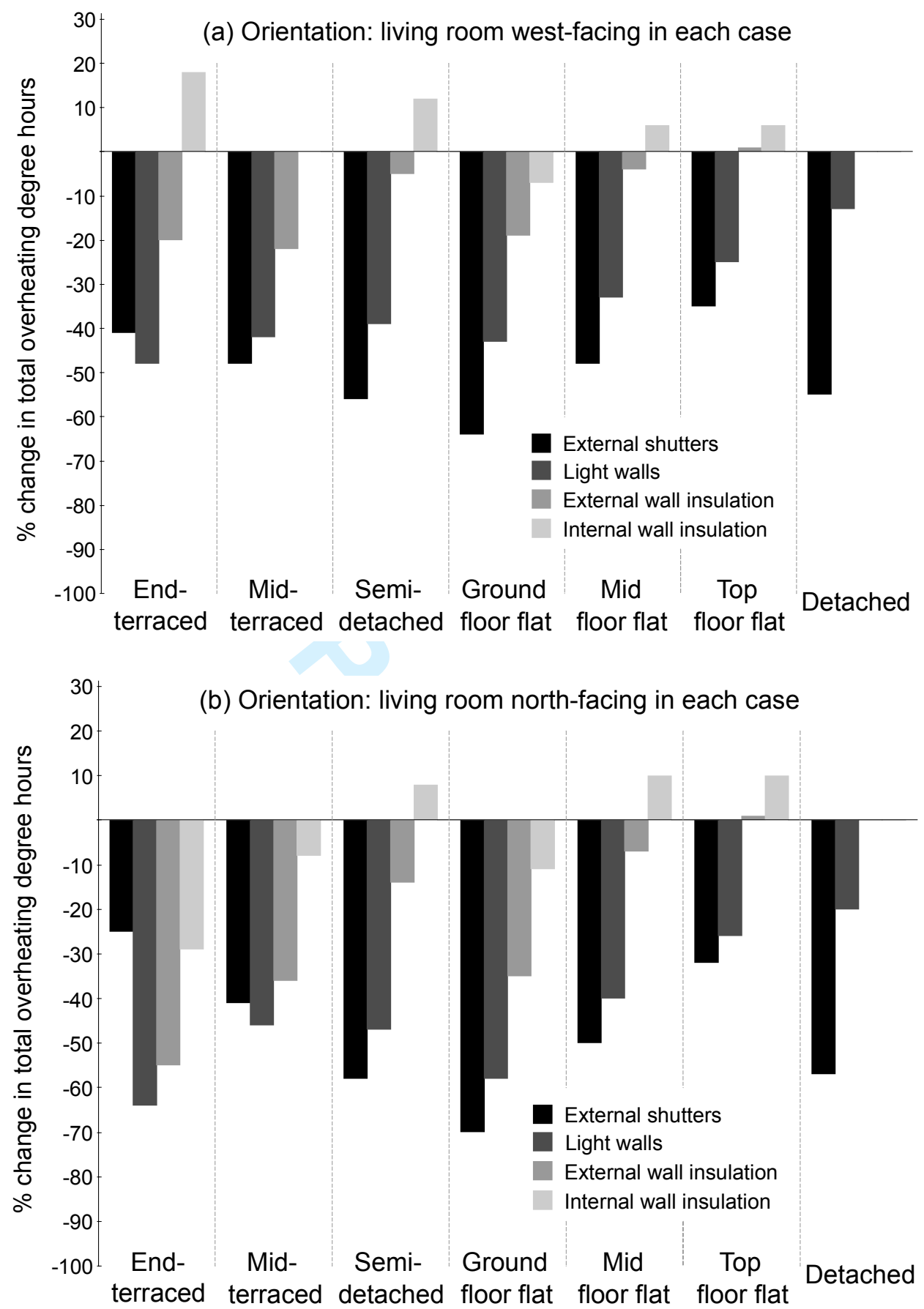

Figure 7. Effect of selected interventions on total overheating exposure

Figure 7 shows the effect of the best performing interventions for overheating reduction (external shutters and light walls) and compares the effect of external and internal wall insulation for the seven dwelling variants. Figure 7(a) shows the percentage change in overheating when the living room windows faced west and Figure 7(b) when they faced north. Note: in the flats and the semi-detached house the main bedroom windows faced the same direction as the living room windows; in the detached and terraced houses the 
main bedroom windows faced the opposite direction (see the methodology section in the Retrofit Toolkit (2012b) for the dwelling floor plans). Note also that no wall insulation upgrades were considered for the modern detached house.

The charts in Figure 7 demonstrate how the effect of the interventions changed for higher solar gain (west-facing) to lower solar gain (north-facing) orientations. External shutters were the most effective single intervention for most dwelling types, with light walls being generally more effective for the terraced houses as discussed earlier. Choice of wall insulation type was seen to be very important. External installation always produced lower total overheating than internal, which in some cases increased overheating compared to the base case dwelling.

\subsection{Combined interventions including cost and heating energy use}

No single intervention was able to eliminate overheating, therefore combinations of interventions were modelled for each dwelling type (see Figure 4). The simulation results were used to produce 56 scatter plots representing the 4 orientations and 2 occupancy profiles for each of the 7 dwelling variants. Each scatter plot contained between 256 points (detached house, with the lowest number of modelled interventions) and 2,048 points (flats and semi-detached house), a total of 92,160 points, each representing either a single intervention or a combination of interventions. Identifying which intervention(s) each point in the scatter plots represented was time consuming and labelling each point in printed versions would be impossible. To enable easy analysis of the results an interactive online toolkit was developed (Porritt, 2012b). The toolkit consists of a set of linked HTML pages displaying bar charts for single interventions and interactive scatter plots for combined interventions. The toolkit allows users to explore the effect of single and combined interventions on both overheating (position along the y-axis) and heating energy use (colour and shape of the marker). The distance along the $\mathrm{x}$-axis gives the cost of the combined package of interventions and hovering the mouse pointer over a marker will produce a pop-up box listing the interventions.

Figure 8 shows a screen shot of one of the scatter plots, for the top floor flat with elderly (daytime) occupancy. The front of the building faced east, resulting in west-facing living room and main bedroom windows. Two examples have been highlighted, the upper marker shows that adding internal wall insulation as a single intervention decreased heating energy use by $20-40 \%$, but increased overheating degree hours by $6 \%$ at an estimated cost of around $£ 5 \mathrm{k}$. The lower highlighted marker shows how internal wall insulation could still be specified as part of a package of measures that resulted in lower overheating. Adding the light roof and light walls interventions, at an estimated additional cost of $£ 1.2 \mathrm{k}$, as well as the behavioural interventions of closing curtains during the daytime and allowing night ventilation, still reduced heating energy use by $20-40 \%$, but reduced overheating by over $50 \%$.

The red and orange markers in the low overheating and low cost (lower left) corner of the scatter plots illustrates how some low cost interventions that are beneficial for overheating reduction result in greater heating energy use. This is due to solar control 
interventions, such as fixed shading and solar reflective coatings (light walls and roof), reducing beneficial solar gains in the winter. Other solar control measures, such as external shutters and curtains, can be used only when required in the summer and therefore do not affect heating energy use.

The results demonstrate that the cost of adaptation to achieve the same level of overheating reduction varied significantly across the dwelling types. Overheating could be eliminated in the ground floor flat with north-facing living room and bedroom windows for around $£ 1 k$, compared to around $£ 32 k$ for the semi-detached house with west-facing windows. For Tier 2 dwellings (mid and top floor flats and the modern detached house), overheating could not be eliminated at any cost by the passive interventions considered in this research and in these cases further measures, including mechanical ventilation, may be required in the future. The results also show that as the cost of retrofit increases there is a diminishing return in the reduction of both overheating and heating energy use.

\section{Adapting Dwellings to Climate Change - Retrofit Advice Tool \\ ( \\ Methodology \\ Plans \\ Detached \\ Terraced \\ Semi-Detached \\ Flats \\ Log out}

\begin{tabular}{|l|}
\hline Flat Type: \\
\hline Ground Floor Flat \\
\hline Mid (1st) Floor Flat \\
\hline Top Floor Flat \\
\hline $\begin{array}{l}\text { Combined } \\
\text { Adaptations: }\end{array}$ \\
\hline $\begin{array}{l}\text { Front of Block North } \\
\text { Daytime Occupied }\end{array}$ \\
\hline $\begin{array}{l}\text { Front of Block South } \\
\text { Daytime Occupied }\end{array}$ \\
\hline $\begin{array}{l}\text { Front of Block East } \\
\text { Daytime Occupied }\end{array}$ \\
\hline $\begin{array}{l}\text { Front of Block West } \\
\text { Daytime Occupied }\end{array}$ \\
\hline $\begin{array}{l}\text { Front of Block North } \\
\text { Daytime Unoccupied }\end{array}$ \\
\hline $\begin{array}{l}\text { Front of Block South } \\
\text { Daytime Unoccupied }\end{array}$ \\
\hline $\begin{array}{l}\text { Front of Block East } \\
\text { Daytime Unoccupied }\end{array}$ \\
\hline $\begin{array}{l}\text { Front of Block West } \\
\text { Daytime Unoccupied }\end{array}$ \\
\hline Back to: \\
\hline Single adaptations \\
\hline
\end{tabular}

Top Floor Flat (Hover the mouse pointer over a symbol to see the list of adaptations)

Daytime Occupied; Front of Block East-facing; West-facing Living Room \& Main Bedroom Windows (Combined Overheating: Living Room + Main Bedroom)

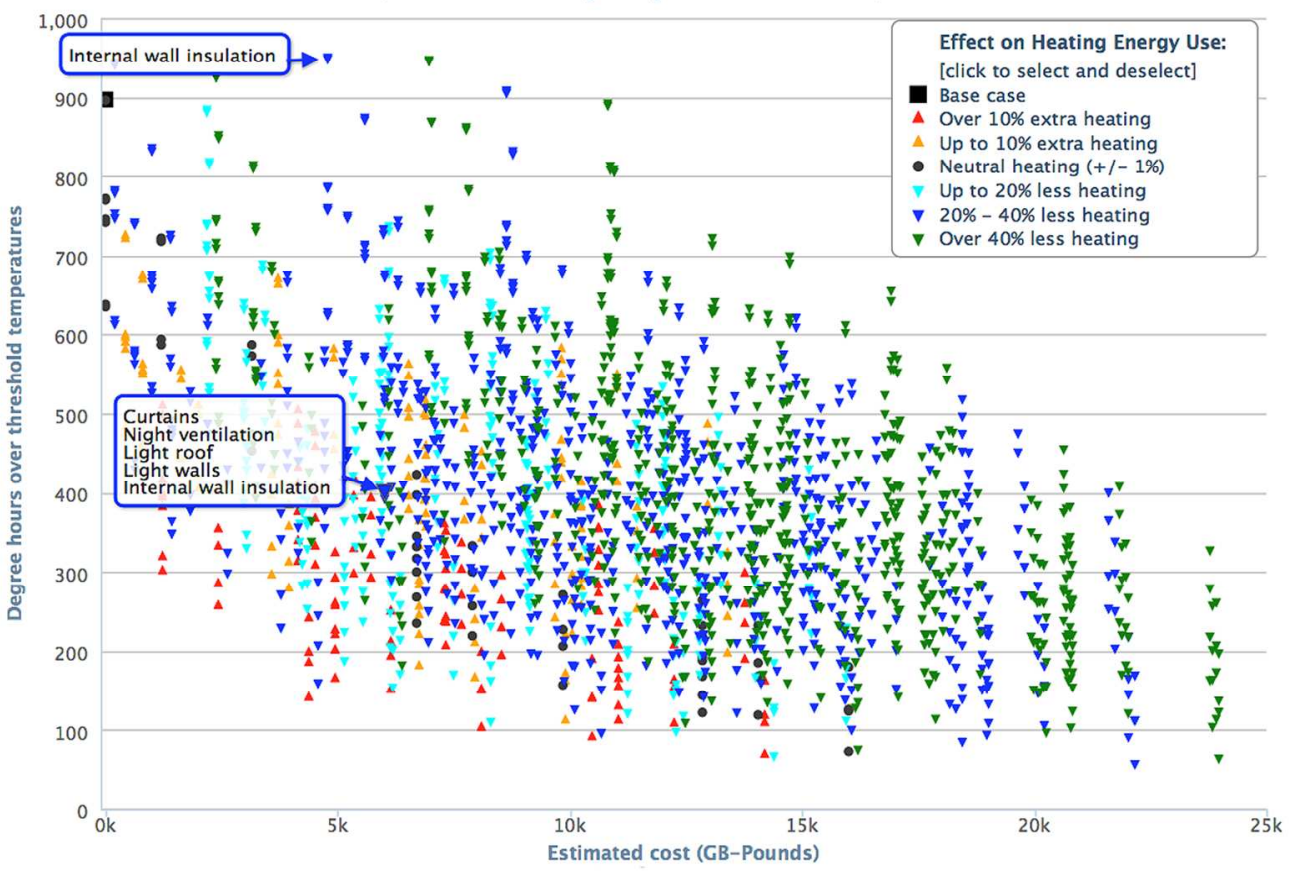

Figure 8. Retrofit toolkit screen shot (Porritt, 2012b) 


\subsection{Mitigation without adaptation}

Several simulations were carried out to assess the impact of a high performance retrofit on the $19^{\text {th }}$ century solid wall end-terraced house. Upgrades to insulation, airtightness and glazing, consistent with the Building Regulations for new dwellings in force at the time of modelling (Office of the Deputy Prime Minister, 2006), were applied to the base case dwelling. Where internal wall insulation was specified the overheating exposure approached the level seen in the modern (2006 Building Regulations) detached house. However, if external wall insulation with a solar reflective outer render coating was specified in preference to internal wall insulation the overheating exposure could be reduced by over $30 \%$, whilst achieving a similar reduction in heating energy use. Given the severity of overheating observed in the 2006 detached house, and the difficulty and cost relating to its rectification, it is advisable to consider adaptation in conjunction with mitigation when a retrofit project is planned.

\section{Conclusions}

A number of key messages have been drawn from the research, with implications for retrofit policy and occupant health and wellbeing.

Of the dwelling types studied, 1960s mid and top floor flats and the modern detached house (Tier 2) experienced more than twice the overheating exposure of the terraced and semi-detached houses and the ground floor flat (Tier 1). Tier 2 dwellings are harder to treat in that overheating could not be eliminated using passive interventions alone. Their cost of adaptation to provide the same (low) level of overheating exposure as Tier 1 dwellings could be many times higher.

External shutters consistently ranked as the single most effective intervention for overheating, typically leading to a $50 \%$ reduction. Integration with future window designs should therefore be considered. The exception to the above was $19^{\text {th }}$ century terraced houses, where the solid walls facilitated inward transmission of solar heat gains and solar reflective coatings applied to the external wall surfaces were the most effective intervention, closely followed by external shutters.

Zero cost behavioural interventions can significantly reduce overheating, such as closing curtains during the daytime and preventing windows from opening when the outside air is warmer than the inside air, although the latter may require some form of warning system to ensure correct operation.

External wall insulation consistently outperformed internal wall insulation, with the latter often leading to increased overheating, although in certain cases (some orientations of the mid and top floor flats) all types of wall insulation increased overheating. However, using the retrofit toolkit shows that all types of wall insulation, when combined with other interventions, can be part of a retrofit strategy that combines low overheating with low heating energy use. 
Residents who occupy their dwellings during the daytime experience much higher overheating exposure, often over twice as high, than those who only occupy their dwellings during the evening. This has implications for the choice of suitable housing for parents with young children, homeworkers and the unemployed, but particularly for the elderly and infirm.

Barriers may exist to some of the modelled interventions. For example, changes to the external appearance of some dwellings may be prohibited by planning or conservation rules. Several of the interventions also require user engagement for correct operation, which may be difficult for some of the more vulnerable members of society. Some interventions may also require the provision of extra information, such as external and internal temperatures to ensure that windows are closed when it is hotter outside than inside. Heat wave and hot weather warning systems could be improved to encourage residents to take appropriate actions such as closing curtains or blinds before leaving their dwellings for the day.

This research demonstrates the importance of combining mitigation with adaptation, both in design practice and regulations, to provide comfortable and efficient homes. If existing dwellings are retrofitted to reduce heating energy use, without considering summertime thermal performance, overheating exposure could increase substantially. These unintended consequences could be important when considering energy efficiency policies. For example, retrofitting old dwellings to achieve modern thermal standards by adding internal wall insulation and improving airtightness could result in significantly greater overheating exposure. However, if alternative insulation options, such as external wall insulation, or other measures to reduce heat gains are implemented at the same time, costly future remedial work could be avoided. The risk of ignoring these issues could be increased cooling energy use and associated $\mathrm{CO}_{2}$ emissions in the future.

\section{References}

Arup (2008). Your home in a changing climate. Retrofitting existing homes for climate change impacts. Report for policy makers. Three Regions Climate Change Group, London.

Belcher SB, Hacker JN, Powell DS (2005) Constructing design weather data for future climates. Building Services Engineering Research and Technology, 26(1): 49-61.

CIBSE (2005) Climate Change and the Indoor Environment: Impacts and Adaptation (TM36). The Chartered Institution of Building Services Engineers. (Principal authors: Hacker, J.N., Holmes, M.J., Belcher, S.B., and Davies, G.D.), London.

CIBSE (2006) Guide A: Environmental Design. The Chartered Institution of Building Services Engineers, London. 
CREW (2012) Community Resilience to Extreme Weather Project. EPSRC grant: EP/F036442/1. Available at: www.extreme-weather-impacts.net Accessed on 11th June 2013.

Davies M, Oreszczyn T (2012) The unintended consequences of decarbonising the built environment: A UK case study. Energy and Buildings, 46: 80-5.

DCLG (2009) English House Condition Survey Public Dataset 2007. EHCS project team, Department for Communities and Local Government, Eland House, London.

DCLG (2012) Investigation into Overheating in Homes: Analysis of Gaps and Recommendations. Department of Communities and Local Government. Available at: http://www.communities.gov.uk/publications/planningandbuilding/overheatinganalysis Accessed on 11th June 2013.

Department of Health (2012) Heatwave Plan for England. Available at: https://www.gov.uk/government/uploads/system/uploads/attachment_data/file/201039/Heat wave-Main_Plan-2013.pdf Accessed on 11th June 2013.

DesignBuilder (2012) DesignBuilder software. Available at: www.designbuilder.co.uk Accessed on 11th June 2013.

Energy Saving Trust (2005) CE129 Energy efficiency best practice in housing: Reducing overheating - a designer's guide. Energy Saving Trust, London.

Energy Saving Trust (2009) Solid wall insulation supply chain review. Purple Market Research for the Energy Saving Trust and the Energy Efficiency Partnership for Homes. Available at: www.eeph.org.uk/resources/ Accessed on 11th June 2013.

Energy Saving Trust (2012) Home improvement products guide. Available at: www.energysavingtrust.org.uk/Home-improvements-and-products/Home-insulation-glazing Accessed on 11th June 2013.

Gaterell MR, McEvoy ME (2005) The impact of climate change uncertainties on the performance of energy efficiency measures applied to dwellings. Energy and Buildings, 37: 982-95.

GLA (2011) Managing risks and increasing resilience: The Mayor's climate change adaptation strategy. Greater London Authority, City Hall, London: Available online: http://www.london.gov.uk/priorities/environment/publications/managing-risks-andincreasing-resilience-the-mayor-s-climate Accessed on 11th June 2013.

Gupta R, Gregg M (2012) Using UK climate change projections to adapt existing English homes for a warming climate. Building and Environment, 55: 20-42.

Hulme M, Jenkins GJ, Lu X, Turnpenny JR, Mitchell TD, Jones RG, Lowe J, Murphy JM, Hassell D, Boorman P, McDonald R, Hill S (2002) Climate Change Scenarios for the United Kingdom: The UKCIP02 Scientific Report. 
Jones P, Harpham C, Kilsby C, Glenis V, Burton A (2010) Online Weather Generator report. UK Climate Projections. Available at: http://ukclimateprojections.defra.gov.uk/22586 Accessed on 11th June 2013.

Langdon D (2011) Spon's Architects' and Builders' Price Book. UK: Spon Press.

Lee SE, Sharples S (2008) An Analysis of the Urban Heat Island of Sheffield - the Impact of a Changing Climate. PLEA 2008 - 25th Conference on Passive and Low Energy Architecture, Dublin, 22nd to 24th October 2008

Mavrogianni A, Davies M, Chalabi Z, Wilkinson P, Kolokotroni M, Milner J (2009) Space heating demand and heatwave vulnerability: London domestic stock. Building Research \& Information, 37(5): 583-97.

Mavrogianni A, Davies M, Batty M, Belcher SE, Bohnenstengel SI, Carruthers D, Chalabi Z, Croxford B, Demanuele C, Evans S, Giridharan R, Hacker JN, Hamilton I, Hogg C, Hunt J, Kolokotroni M, Martin C, Milner J, Rajapaksha I, Ridley I, Steadman JP, Stocker J, Wilkinson P, Ye Z (2011) The comfort, energy and health implications of London's urban heat island. Building Services Engineering Research and Technology, 32(1): 35-52.

Mavrogianni A, Wilkinson P, Davies M, Biddulph P, Oikonomou E (2012) Building characteristics as determinants of propensity to high indoor summer temperatures in London dwellings. Building and Environment, 57(3): 583-97.

Murphy JM, Sexton DMH, Jenkins, G J Booth,B B B., Brown CC, Clark RT, Collins M, Harris GR, Kendon EJ, Betts RA, Brown SJ, Humphrey KA, McCarthey MP, McDonald RE, Stephens A, Wallace C, Warren R, Wilby R, Wood RA (2009) UK Climate Change Projections Science Report: Climate change projections. Met Office Hadley Centre, Exeter, UK.

Office of the Deputy Prime Minister (2006) The Building Regulations 2000. Conservation of Fuel and Power Part L1B conservation of fuel and power in existing dwellings 2006 Edition. NBS for the Office of the Deputy Prime Minister, London.

ONS (2003) United Kingdom Time Use Survey, 2000. Office for National Statistics. Newport, South Wales, UK.

Orme M, Palmer J (2003) Control of overheating in future housing - design guidance for low energy strategies. Report by Faber Maunsell for the DTI Partners in Innovation Programme. St Albans, UK.

Porritt SM (2012a) Adapting UK Dwellings for Heat Waves. PhD Thesis, Institute of Energy and Sustainable Development, De Montfort University, UK. Available at: http://hdl.handle.net/2086/6327.

Porritt SM (2012b) Retrofit toolkit. Available at: www.iesd.dmu.ac.uk/crew Accessed on 11th June 2013.

Porritt SM, Cropper PC, Shao L, Goodier Cl (2012) Ranking of interventions to reduce dwelling overheating during heat waves. Energy and Buildings, 55: 16-27. 
Robine J, Cheung SLK, Le Roy S, Van Oyen H, Griffiths C, Michel J, Herrmann FR (2008) Death toll exceeded 70,000 in Europe during the summer of 2003. Comptes Rendus Biologies, 331(2): 171-8.

Smith C, Lindley S, Levermore G (2009) Estimating spatial and temporal patterns of urban anthropogenic heat fluxes for UK cities: the case of Manchester. Theoretical and Applied Climatology, 98(1-2): 19-35.

U.S. Department of Energy (2010) EnergyPlus software and documentation. Available at: http://apps1.eere.energy.gov/buildings/energyplus/ Accessed on 11th June 2013.

U.S. Department of Energy (2012) EnergyPlus Testing and Validation. Available at: http://apps1.eere.energy.gov/buildings/energyplus/energyplus testing.cfm Accessed on 11 th June 2013.

UK Meteorological Office (2012) MIDAS Land Surface Stations data (1853-current). Available at: http://badc.nerc.ac.uk Accessed on 11th June 2013.

Vandentorren S, Bretin P, Zeghnoun A, Mandereau-Bruno L, Croisier A, Cochet C, Riberon J, Siberan I, Declercq B, Ledrans M (2006) August 2003 heat wave in France: Risk factors for death of elderly people living at home. European journal of public health, 16(6): 583-91.

Wright A, Young A, Natarajan S (2005) Dwelling temperatures and comfort during the August 2003 heat wave. Building Services Engineering Research and Technology, 26(4): 285-300.

Zhang Y (2009) "Parallel" EnergyPlus and the development of a parametric analysis tool. Eleventh International IBPSA Conference, Glasgow, UK. July 27-30 2009: 1382-8. 